ARQGA/1192

\title{
HIGH SERUM LAMININ AND TYPE IV COLLAGEN LEVELS IN SCHISTOSOMIASIS MANSONI
}

\author{
Rozangela Maria de Almeida Fernandes WYSZOMIRSKA ${ }^{1}$, \\ Nancy Fusae NISHIMURA², Jazon Romilson Souza ALMEIDA², \\ Ademar YAMANAKA ${ }^{2}$ and Elza Cotrim SOARES ${ }^{2}$
}

\begin{abstract}
Background - Fibrosis is the process of excessive deposition of collagen and other extra cellular matrix components and large amounts of these components have been shown in periovular schistosomal granulomas, especially in the liver. Laminin and type IV collagen have been investigated in various hepatic disorders but their accuracy in fibrosis detection and in the evaluation of its progression in schistosomiasis have not been fully explained. Aim - To measure the serum levels of two markers of fibrosis, laminin and type IV collagen in schistosomiasis. Patients and Methods - Sixty-four patients with different clinical forms of schistosomiasis mansoni: intestinal (group I), hepatointestinal (group II), compensated (group III) and decompensated hepatosplenic (group IV) and 18 healthy volunteers were included. Results - Serum type IV collagen and laminin levels were significantly increased in patients compared to controls. At about clinical forms, serum type IV collagen was increased in groups II and IV, compared to controls and was significantly higher in group IV than in group I. Serum laminin was significantly increased in groups II, III and IV and was significantly higher in group IV than in group II. Serum type IV collagen was closely correlated with serum laminin in groups II and IV. Conclusions - Connective tissue marker levels did not correlate with periportal thickness. In schistosomiasis mansoni there is an increase of type IV collagen and laminin levels at the initial stage of the disease, as well as in advanced forms. We also suggest that these markers may be a useful predictor of disease progression.
\end{abstract}

HEADINGS - Schistosomiasis mansoni. Collagen type IV. Laminin. Liver cirrhosis.

\section{INTRODUCTION}

Schistosomiasis mansoni is the most common fibrotic disease worldwide. It is usually characterized by an unnoticed acute phase, followed by a chronic phase that can present a few or no clinical manifestations. In some cases it can progress to more aggressive forms, associated with the development of periportal fibrosis ${ }^{(7)}$, and portal hypertension ${ }^{(18)}$. Some patients can present sinusoidal reaction with hypertrophy and stratification of the endothelium and perisinusoidal fibrosis ${ }^{(2,10)}$. These changes lead to the deposition of key components of the basal membrane, namely laminin and type IV collagen around the basal membrane of surrounding blood vessels and bile ducts ${ }^{(14,16)}$. An increased deposit of extra cellular matrix components has been observed, such as type III collagen in the fibrotic process, and types I and II collagen, fibronectin and proteoglycan at various stages of granuloma formation ${ }^{(1,11,13,30)}$.
Different diagnostic approaches, such as liver biopsy ${ }^{(15,29)}$, serum markers by immunoradiometric (RIA), immunoenzymatic (EIA) and immunoelectrophoretic method have been used in order to detect liver fibrosis at early phases ${ }^{(4,5)}$. There have been difficulties in establishing which of these is at the same time less invasive and a reliable method to be used in schistosomiasis patients, and the diagnostic value of the serum markers is still inaccurate ${ }^{(12,20,21,23)}$. In advanced forms of schistosomiasis, liver ultrasonography, a non-invasive method, can be performed on a large number of patients and has an adequate sensitivity and specificity in the detection of periportal fibrosis ${ }^{(19,27)}$. The World Health Organization has recommended its use in schistosomiasis patients while also proposing guidelines for an adequate examination ${ }^{(28)}$.

Our aim was to determine serum type IV collagen and laminin levels in different clinical forms of patients with schistosomiasis.

\footnotetext{
Department of Internal Medicine, University of Alagoas, Maceió, AL; ${ }^{2}$ Faculty of Medical Sciences, State University of Campinas, Campinas, SP, Brazil Address for correspondence: Dra. Rozangela M. Almeida Fernandes Wyszomirska - Desportista Humberto Guimarães, $342 / 201$ - Ponta Verde - 57035 - 030 - Maceió, AL., Brazil. E-mail: rozangelaf@uol.com.br
} 


\section{PATIENTS AND METHODS}

Sixty-four consecutive patients diagnosed with schistosomiasis mansoni (31 male and 33 female, mean age 39.11 \pm 14.79 years, range 14-74 years) between April 1996 and July 1997 at the Liver Clinic, University of Campinas Medical Hospital, Campinas, SP, Brazil, were enrolled in this study. Schistosomiasis was diagnosed by the presence of the $S$. mansoni ova in stool samples, and/or rectal biopsy, and by liver ultrasonography. Exclusion criteria were pregnancy, alcoholism, chronic active hepatitis, positive serology for HIV and hepatitis B or C, and the presence of other infectious diseases affecting the liver.

Patients were separated into four groups for different clinical forms: intestinal, hepatointestinal, compensated hepatosplenic and decompensated hepatosplenic, according to Coutinho's criteria $^{(7)}$ (Figure1). Another group, composed of 18 healthy volunteers (10 male and 8 female, mean age $37.61 \pm$ 10.42 years, range $24-59$ years) was also included as determined by medical history, physical examination, absence of alcoholism and conventional laboratory screening, including negative serology for HIV (EIA), hepatitis B and C.

\begin{tabular}{|ll|}
\hline Clinical form & Parameters \\
\hline Group I - & \\
Intestinal form (FI) & Presence of $S$. mansoni ova \\
& No hepatomegaly \\
Group II - & Presence of $S$. mansoni ova \\
Hepatointestinal (HI) & Hepatomegaly \\
& \\
Group III - & Presence of $S$. mansoni ova \\
Hepatosplenic compensated (HSC) & Hepatomegaly \\
& Splenomegaly \\
Group IV - & Presence of $S$. mansoni ova \\
Hepatosplenic decompensated (HSD) & $\begin{array}{l}\text { Hepatomegaly } \\
\text { Splenomegaly } \\
\text { Esophageal varices hemorrhage or ascitis or } \\
\text { evidence of jaundice }\end{array}$ \\
\end{tabular}

FIGURE 1 - Classification of clinical forms in schistosomiasis according to Coutinho ${ }^{(7)}$

The study was approved by the State University of Campinas Medical School Ethics Committee, and performed according to the Declaration of Helsinki. All subjects signed a written informed consent form prior to entering the study.

Laboratory screening consisted of complete blood count, determination of AST, ALT, alkaline phosphatase, $\gamma$-glutamyl transpeptidase $(\gamma \mathrm{GT})$, and bilirrubin levels. Prothrombin time and serology for HIV (EIA), hepatitis B and C were also determined.

All patients and healthy volunteers underwent liver ultrasonography according to the World Health Organization (WHO) protocol ${ }^{(28)}$ using a Toshiba Sonolayer SSA, 3.75 MHz and linear/convex probe (Japan). The criteria are shown in Figure 2.

\begin{tabular}{|c|c|}
\hline Ultrasound parameters & Measurement \\
\hline Right lobe (mm) & $\begin{array}{l}\text { Up to } 140 \text { - normal } \\
\text { Less than } 140 \text { - decreased }\end{array}$ \\
\hline Left lobe (mm) & $\begin{array}{l}\text { Less than } 70 \text { - normal } \\
\text { Up to } 70 \text { - increased }\end{array}$ \\
\hline Periportal thickness (mm) & $\begin{array}{l}\text { Grade } 0 \text { - less than } 3 \\
\text { Grade I - between } 3 \text { and } 5 \\
\text { Grade II - over } 5 \text { and up to } 7 \\
\text { Grade III - above } 7\end{array}$ \\
\hline Portal vein diameter $(\mathrm{mm})$ & $\begin{array}{l}\text { Less } 12 \text { - normal } \\
\text { Up to } 12 \text { - increased }\end{array}$ \\
\hline Spleen size $(\mathrm{mm})$ & $\begin{array}{l}\text { Less } 120-\text { normal } \\
\text { Up to } 120 \text { - increased }\end{array}$ \\
\hline Gallbladder wall thickness ( $\mathrm{mm}$ ) & $\begin{array}{l}\text { Less } 5 \text { - normal } \\
\text { Up to } 5 \text { - increased }\end{array}$ \\
\hline Ascitis & $\begin{array}{l}\text { Absence - normal } \\
\text { Presence - positive for ascitis }\end{array}$ \\
\hline
\end{tabular}

FIGURE 2 - Ultrasound parameters according to World Health Organization protocol ${ }^{(28)}$

Blood samples were collected from all the subjects, the serum separated and stored at $-20^{\circ} \mathrm{C}$ until assayed for laminin and type IV collagen levels. An immunoenzymatic sandwich method (EIA) with monoclonal antibodies (hLM and Panassay IV $-\mathrm{C}$ kits, respectively, was used. (Fuji Chemical Industries, Takaoka, Japan).

All values are expressed as mean \pm s.e.m. The means were compared using the Kruskal-Wallis and Wilcoxon tests. The Pearson linear coefficient was used to evaluate the correlation between the periportal thickness measured by ultrasonography and the serum levels of laminin as well as the periportal thickness and the serum levels of type IV collagen. The same method was used to determine the correlations between type IV collagen and laminin. Tests were considered statistically significant at $P<0.05$.

\section{RESULTS}

The healthy volunteers had normal laboratory screening, including normal ultrasonography. All schistosomiasis patients had negative markers for hepatitis B and C, as well as negative serology for HIV. Except for groups III and IV, AST, ALT, alkaline phosphates, $\gamma \mathrm{GT}$ and bilirubin levels were within normal range (Table 1).

Ultrasonography scans have demonstrated reduction of the right lobe and increase of the left lobe of the liver, particularly in-group IV (data not shown). There was a significant increase $(P<0.05)$ in periportal thickness in groups 
TABLE 1 - Conventional liver function tests of patients with different clinical forms of schistosomiasis

\begin{tabular}{|c|c|c|c|c|}
\hline \multicolumn{5}{|c|}{ Clinical forms } \\
\hline Parameters & $\begin{array}{l}\text { Group I } \\
(\mathrm{n}=18)\end{array}$ & $\begin{array}{c}\text { Group II } \\
(\mathrm{n}=17)\end{array}$ & $\begin{array}{c}\text { Group III } \\
(\mathrm{n}=12)\end{array}$ & $\begin{array}{c}\text { Group IV } \\
(\mathrm{n}=17)\end{array}$ \\
\hline Leukocyte count & $6.798 \pm 463.1$ & $6.376 \pm 419.1$ & $3.280 \pm 374.1$ & $4.670 \pm 496.7$ \\
\hline $\operatorname{AST}(\mathrm{U} / \mathrm{l})$ & $23.7 \pm 1.6$ & $25.5 \pm 2.7$ & $32.4 \pm 2.5$ & $43.0 \pm 4.2$ \\
\hline $\operatorname{ALT}(\mathrm{U} / \mathrm{l})$ & $22.0 \pm 2.3$ & $25.8 \pm 3.8$ & $28.6 \pm 4.0$ & $34.4 \pm 4.3$ \\
\hline$\gamma-\mathrm{GT}(\mathrm{U} / \mathrm{l})$ & $52.8 \pm 6.9$ & $82.9 \pm 21.0$ & $34.7 \pm 4.0$ & $117.9 \pm 28.3$ \\
\hline Alkaline phosphatase $(\mathrm{U} / \mathrm{l})$ & $157.8 \pm 53.8$ & $138.5 \pm 18.4$ & $178.4 \pm 24.0$ & $250.4 \pm 35.8$ \\
\hline Albumin $(\mathrm{g} / \mathrm{L})$ & $3.9 \pm 0.2$ & $4.2 \pm 0.1$ & $3.7 \pm 0.1$ & $3.5 \pm 0.1$ \\
\hline Direct bilirrubin $(\mathrm{mg} / \mathrm{dL})$ & $0.5 \pm 0.05$ & $0.9 \pm 0.02$ & $1.3 \pm 0.2$ & $1.1 \pm 0.1$ \\
\hline Platelet count $\left(\mathrm{x} 10^{3} / \mathrm{mm}^{3}\right)$ & $235.9 \pm 11.0$ & $209.5 \pm 18.2$ & $70.6 \pm 9.7$ & $136.1 \pm 30.1$ \\
\hline
\end{tabular}

III and IV ( $4.2 \pm 1.1 \mathrm{~mm}$ and $4.5 \pm 1.6 \mathrm{~mm}$, respectively), compared to controls $(0.8 \pm 0.6 \mathrm{~mm})$. In addition, there was a significant increase $(P<0.05)$ in periportal thickness in groups III and IV compared to group I and in group IV compared to group II.

\section{Type IV collagen}

Mean serum type IV collagen was significantly increased $(P<0.001)$ in schistosomiasis patients, compared to controls $(92.3 \pm 54.3 \mathrm{ng} / \mathrm{mL}$ vs. $57.7 \pm 18.0 \mathrm{ng} / \mathrm{mL}$, respectively $)$.

Type IV collagen levels were also significantly increased $(P<0.05)$ in groups II and IV compared to the control group $(P<0.05)$ (Table 2$)$ and in group IV compared to group I $(P$ $<0.05$ ) (Figure 3).

TABLE 2 - Serum levels of type IV collagen and laminin in different clinical forms of schistosomiasis as compared to control subjects

\begin{tabular}{ccc}
\hline Clinical forms & $\begin{array}{c}\text { Type IV collagen }(\mathrm{ng} / \mathrm{mL}) \\
\text { mean } \pm \text { SD }\end{array}$ & $\begin{array}{c}\text { Laminin }(\mathrm{ng} / \mathrm{mL}) \\
\text { mean } \pm \text { SD }\end{array}$ \\
\hline Group I & $82.7 \pm 51.23$ & $326.4 \pm 79.8$ \\
Group II & $107.7 \pm 709^{*}$ & $373.4 \pm 94.0^{* *}$ \\
Group III & $86.6 \pm 42.0$ & $437.9 \pm 184.9^{*}$ \\
Group IV & $135.1 \pm 60.7^{*}$ & $436.7 \pm 69.5^{*}$ \\
Controls & $57.2 \pm 18.04$ & $289.7 \pm 50.9$ \\
\hline
\end{tabular}

Group I intestinal form; group II hepatointestinal form; group III compensated hepatosplenic form; group IV decompensated hepatosplenic form

*significant at $P<0.05$

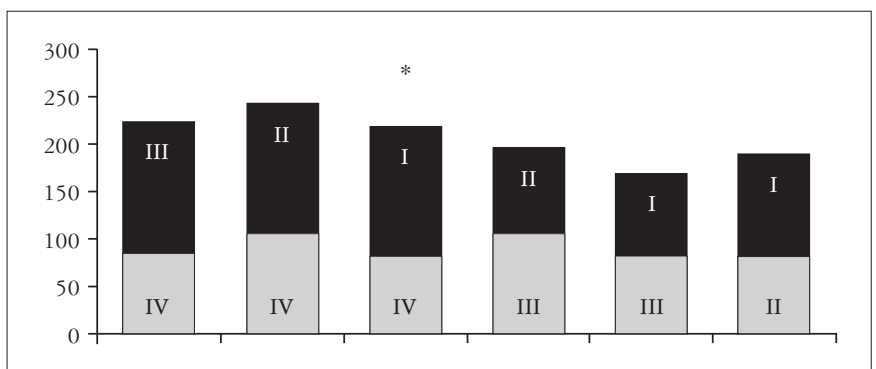

FIGURE 3 - Serum type IV collagen compared to different clinical forms of schistosomiasis

I: intestinal form; II: hepatointestinal form; III: compensated hepatosplenic form;

IV: decompensated hepatosplenic form
* significant at $P<0.05$

\section{Laminin}

Similarly, mean serum laminin was also significantly increased $(P<0.001)$ in schistosomiasis patients $(367.3 \pm 112.6 \mathrm{ng} / \mathrm{mL}$ vs. $289.7 \pm 50.9 \mathrm{ng} / \mathrm{mL})$, and in groups II, III and IV compared to controls $(P<0.05)$ (Table 2$)$ and in groups III/IV compared to group I $(P<0.05)$ (Figure 4$)$.

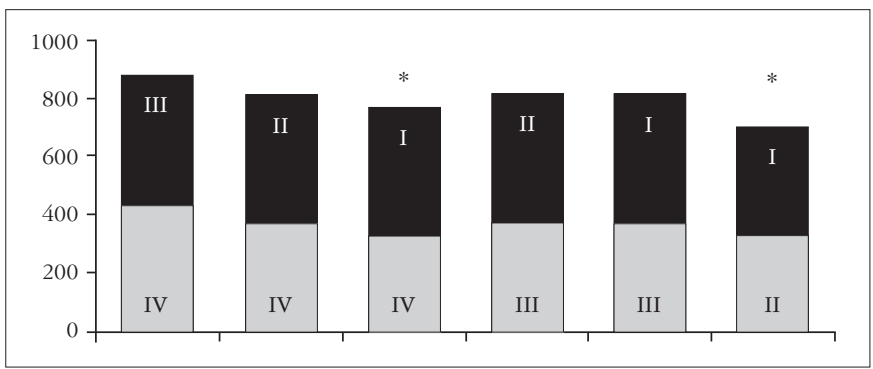

FIGURE 4 - Serum laminin compared to different clinical forms of schistosomiasis

Group I intestinal form; group II hepatointestinal form; group III compensated hepatosplenic form; group IV decompensated hepatosplenic form

*significant at $P<0.05$

We found a positive correlation $(\mathrm{r}=0.464 ; P<0.05)$ between type IV collagen and laminin results in schistosomiasis patients (Figure 5), mainly in groups II and IV $(\mathrm{r}=0.740 ; P<0.05$ and $\mathrm{r}=0.583 ; P<0.05$ respectively) (Figure 6).

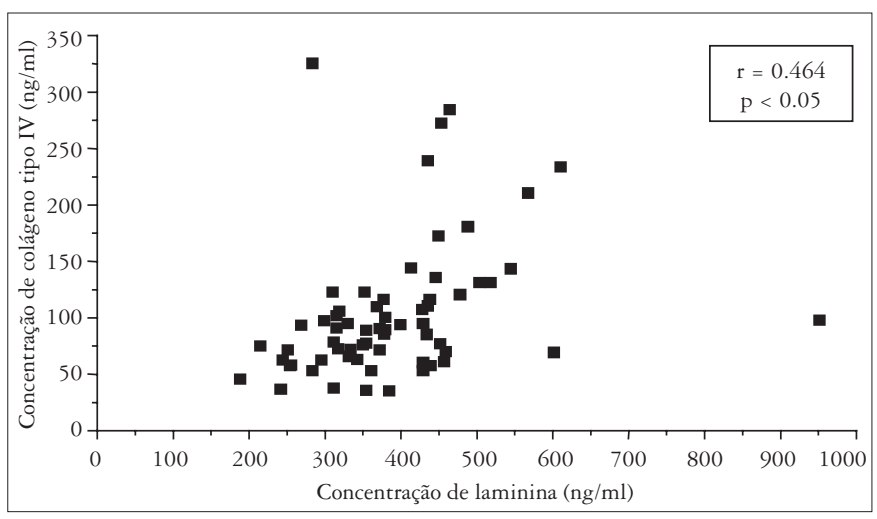

FIGURE 5 - Mean type IV collagen correlated with mean laminin in patients with schistosomiasis

*significant at $P<0.05$ 


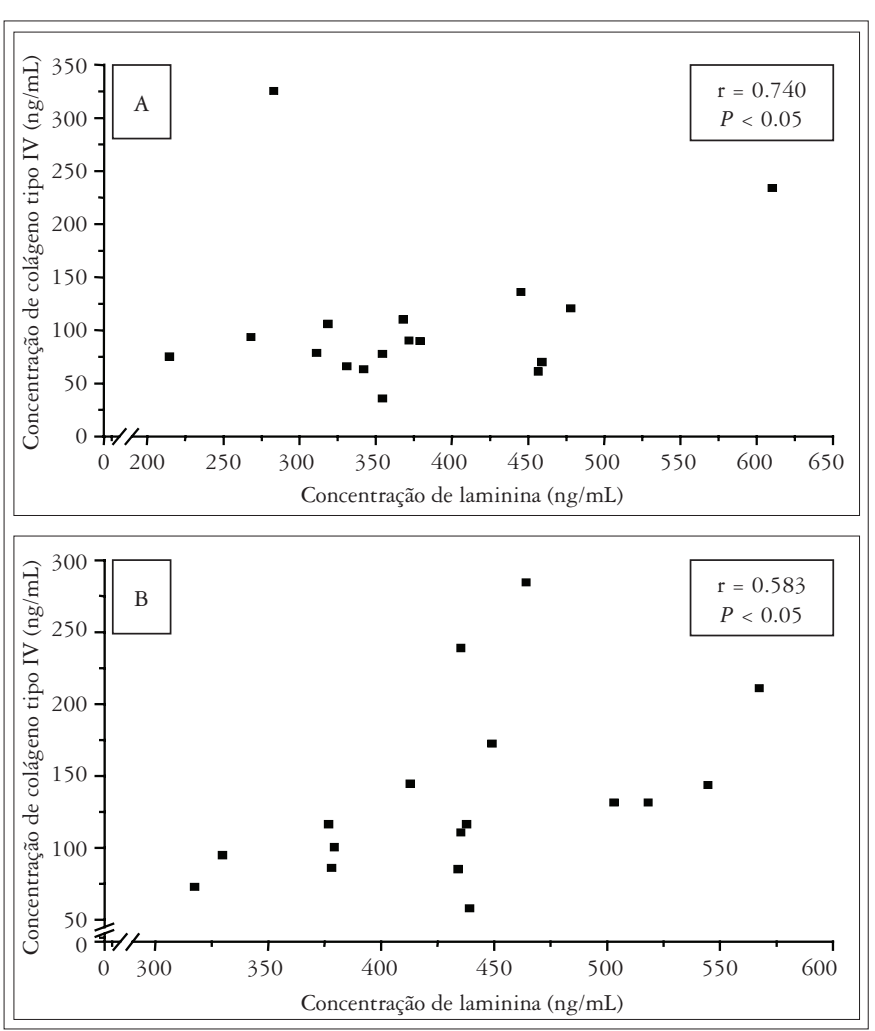

FIGURE 6 - Mean type IV collagen correlated with mean laminin in-group II (A) and in-group IV (B) of schistosomiasis patients

*significant at $P<0.05$

No correlation was found between the degree of fibrosis measured by ultrasound and the levels of type IV collagen or between periportal thickness and laminin.

\section{DISCUSSION}

The present study was carried out to study matrix components, such as type IV collagen and laminin and their relationship with different forms of schistosomiasis mansoni.

In hepatosplenic schistosomiasis patients (groups III and IV), conventional liver function test results were slightly altered, but normal in all other groups.

Mean serum levels of type IV collagen were increased in all the groups. However, these results were statistically significant $(P<0.05)$ only in groups II and IV.

Some authors have shown that type IV collagen is correlated to hepatic fibrosis in alcohol liver disease mainly in early stages ${ }^{(3,}$ ${ }^{6,26)}$. Nevertheless, SHAHIN et al. ${ }^{(22)}$ suggested that in contrast to alcoholic disease type IV, procollagen was only increased in the late stages of schistosomiasis, thus being a good marker for advanced stages of fibrosis. In this same study the patients were classified into three different forms: a simple clinical form without hepatic involvement compensated hepatosplenic and decompensated hepatosplenic.

In our study, higher levels of type IV collagen were found in patients with hepatointestinal schistosomiasis, who were at an early stage of hepatic involvement. However, these higher levels were also found in those at advanced stages of the disease (group IV), compared to controls. We used Coutinho's criteria $^{(7)}$, which present the clinical forms of the disease such as: intestinal, hepatointestinal, compensated hepatosplenic, and decompensated hepatosplenic forms. The different standards used in this classification might contribute towards the inconsistency of some data. Our results suggest that type IV collagen could be a marker for liver fibrosis in schistosomiasis in an early and later form of the disease.

In relation to laminin, the results showed high levels in all the groups but statistically significant $(P<0.05)$ in groups II, III and IV. PARISE and ROSA ${ }^{(17)}$, using a radioimmunoassay method, found the laminin levels significantly higher in schistosomiasis patients, in accordance with our results. Similar results were found by COLLAZOS et al.(6), who demonstrated high serum levels of laminin in alcohol liver disease and liver cirrhosis.

An interesting aspect of our study was the positive correlation between type IV collagen and laminin levels in groups II and IV of schistosomiasis. TSUTSUMI et al. ${ }^{(25)}$ showed a positive correlation between type IV collagen and laminin in alcohol liver disease at an early stage of the disease, but the correlation diminished with the progression of the disease. They suggest that the initial syntheses of matrix components were high in the initial stage, decreasing with the progression of the disease. In contrast, we found a positive correlation with the progression of schistosomiasis, indicating a steady increase of type IV collagen and laminin, in advanced forms of the disease.

Different protocols for the evaluation of fibrosis in the hepatosplenic form of schistosomiasis showed that ultrasonography is an adequate method for the diagnosis of hepatic fibrosis in advanced disease ${ }^{(8,9)}$. In our study, ultrasonography proved to be an adequate method for the diagnosis of hepatic fibrosis when important alterations, such as the periportal thickness, have already taken place. Nevertheless, we did not find a correlation between the ultrasonographic results and type IV collagen and laminin levels. Since type IV collagen and laminin can be detected at early stages, this could be useful in Public Health Services.

Thus, in schistosomiasis mansoni we can observe an increase of type IV collagen and laminin levels at the initial stage of the disease as well as in advanced forms. It is possible that after a substantial increase in basal levels, compatible with activation of matrix components, these markers became stable as the process became quiescent, and finally reaching higher levels that are correlated with advanced fibrosis. But further studies are necessary to clarify the predictive power of these serum markers.

In addition, ultrasonography seems to be an efficient method for detecting hepatic fibrosis particularly at advanced stages. 
Wyszomirska RMAF, Nishimura NF, Almeida JRS, Yamanaka A, Soares EC. Elevação dos níveis séricos de laminina e colágeno tipo IV na esquistossomose mansoni. Arq Gastroenterol 2005;42(4):221-5.

RESUMO - Racional - A fibrose hepática é caracterizada por um aumento progressivo na quantidade do tecido conjuntivo hepático, que é formado pelo aumento na deposição de componentes da matriz extracelular, tendo sido encontrada grande quantidade desses componentes no fígado de pacientes com esquistossomose mansoni. A laminina e o colágeno tipo IV têm sido investigados em várias doenças hepáticas, mas seu papel na esquistossomose ainda não está esclarecido. Objetivos - Avaliar a fibrose hepática na esquistossomose mansoni através da determinação sérica de laminina e colágeno tipo IV, considerados marcadores séricos de fibrose hepática. Pacientes e Métodos - Foram incluídos 82 indivíduos, sendo 18 indivíduos normais, como controle e 64 pacientes com esquistossomose mansoni, em suas diferentes formas clínicas: intestinal (grupo I), hepatointestinal (grupo II), hepatoesplênica compensada (grupo III) e hepatoesplênica descompensada (grupo IV). Os níveis séricos de laminina e colágeno tipo IV foram determinados por método imunoenzimático sanduíche. Resultados - Os valores médios de colágeno tipo IV e laminina estiveram significativamente aumentados em pacientes com esquistossomose, quando comparados com os controles. Em relação às formas clínicas, os níveis séricos de colágeno tipo IV estiveram significativamente aumentados nos grupos II e IV, em relação aos controles e entre as formas hepatoesplênica descompensada e intestinal. Os níveis séricos de laminina estiveram significativamente aumentados nos grupos II, III e IV e entre o grupo IV e II. Não foi encontrada correlação entre os valores médios de colágeno tipo IV e laminina com o grau de espessamento periportal, detectado por ultra-sonografia. Foi encontrada correlação positiva entre colágeno tipo IV e laminina nos grupos II e IV. Conclusões - Os resultados mostram que existe aumento de produção de colágeno tipo IV e laminina na esquistossomose mansoni, surgindo altos níveis desde as fases iniciais do envolvimento hepático da doença, até as formas mais avançadas, sugerindo ser um útil fator para detecção de progressão da doença.

DESCRITORES - Esquistossomose mansoni. Colágeno tipo IV. Laminina. Cirrose hepática.

\section{REFERENCES}

1. Andrade ZA, Peixoto E, Guerret S, Grimaud JA. Hepatic connective tissue changes in hepatosplenic schistosomiasis. Hum Pathol 1992;23:566-73

2. Bolarin DM, Phil D. Sequential observation of pathomorphological alterations in liver of experimental murine schistosomiasis mansoni. Acta Morphol Hung 1991;39:169-75.

3. Chossegros P. Extracellular matrix serum markers (ECMSM) in alcoholic liver disease. J Hepatol 1995;22:96-9.

4. Clément B, Grimaud JA, Campion JP, Deugnier Y, Guillouzo A. Cell types involved in collagen and fibronectin production in normal and fibrotic human liver. Hepatology 1986;6:225-34

5. Clément B, Loréal O, Levavasseur F, Guillouzo A. New challenges in hepatic fibrosis. J Hepatol 1993;18:1-4.

6. Collazos J, Diaz F, Genollá J. Serum concentrations of laminin in cirrhosis of the liver. Gut 1993;34:974-6.

7. Coutinho A. Hemodynamic studies of portal hypertension in schistosomiasis. Am J Med 1968;44:547-56.

8. Domingues ALC, Lima ARF, Dias HS, Leão GC, Coutinho A. An ultrasonographic study of liver fibrosis in patients infected with Schistosoma mansoni in north-east Brazil. Trans R Soc Trop Med Hyg 1993;87:555-8.

9. Fataar S, Bassiony H, Satyanath S, Vassileva J, Hanna RM. Characteristic sonographic features of schistosomal periportal fibrosis. AJR Am J Roentgenol 1984;143:69-71

10. Grimaud JA, Borojevic R. Chronic human schistosomiasis mansoni. Pathology of the Disse's space. Lab Invest 1977;36:268-73.

11. Hayasaka A, Schuppan D, Ohnishi K, Okuda K, Hahn EG. Serum concentration of the carboxyterminal cross-linking domain of procollagen type IV (NC1) and the aminoterminal propeptide of procollagen type III (PIIIP) in chronic liver disease. J Hepatol 1990;10:17-22.

12. Kondo M, Miszputen SJ, Leite-mor MM, Parise ER. The predictive value of serum laminin for the risk of variceal bleeding related to portal pressure levels. Hepatogastroenterol 1995;42:542-5.

13. Kresina TF, He Q, Degli Esposti S, Zern MA. Gene expression of transforming growth factor 1 and extracelular matrix proteins in murine Schistosoma mansoni infection. Gastroenterol 1994;107:773-80.

14. Levavasseur F, Loréal O, Liétard J, Théret N, L'Helgoualc'h A, Guillouzo A, Clément B. Basement membrane gene expression in the liver. J Hepatol 1995;22:10-9.

15. Mincis M, Braga LL, Russo EM, Novo NF, Juliano Y. Serum type III procollagen peptides in patients with hepatointestinal and compensated hepatosplenic schistosomiasis forms. Arq Gastroenterol 1990;27:24-9.

16. Parise EP, Summerfield JA, Hahn E, Wiedmann KH, Doenhoff MJ. Basement membrane proteins and type III procollagen in murine schistosomiasis. Trans R Soc Trop Med Hyg 1985;79:663-70.
17. Parise ER, Rosa H. Serum laminin in hepatic Schistosomiasis. Trans R Soc Trop Med Hyg 1992;86:179-81.

18. Raia S, Mies S, Macedo AL. Portal hypertension in schistosomiasis. Clin Gastroenterol $1985 ; 14: 57-82$.

19. Ravera M, Reggiori A, Cocozza E, Andreata M, Ciantia F, Riccioni G. Clinical aspects and imaging patterns with ultrasonography and endoscopy in hepatosplenic schistosomiasis in Uganda. East Afr Med J 1996;73:228-32.

20. Schuppan D. Connective tissue polypeptides in serum as parameters to monitor antifibrotic treatment in hepatic fibrogenesis. J Hepatol 1991;13:s17-s25.

21. Schuppan D, Stolzel U, Oesterling C, Somasundaram R. Serum assays for liver fibrosis. J Hepatol 1995;22:82-8.

22. Shahin M, Schuppan D, Waldherr R, Risteli J, Risteli L, Savolainen ER, Oesterling C, Rahman HM, el Sahly AM, Razek SM, El Ruby O, Koch A, Seitz HK. Serum procollagen peptides and collagen type VI for the assessment of activity and degree of hepatic fibrosis in schistosomiasis and alcoholic liver disease. Hepatology 1992; 15:637-44.

23. Trinchet JC. Clinical use of serum markers of fibrosis in chronic hepatitis. J Hepatol 1995;22:89-95.

24. Tseng SCG, Smuckler EA, Stern R. Types of collagen synthesized by normal rat liver hepatocytes in primary culture. Hepatology 1983;3:955-63.

25. Tsutsumi M, Urashima S, Nakase K, Takada A. Changes in laminin content in livers of patients with alcoholic liver disease. Liver 1995;15:324-31.

26. Tsutsumi M, Urashima S, Nakase K, Takase S, Takada A. Type IV Collagen and laminin contents of livers from patients with alcoholic liver disease. Alcohol Alcoholism $1993 ; 28: 45-52$.

27. Weimin C, Zhi C, Feng C, Cheng Z, Ronghua L, Jingxiang W. Changes of ultrasonography and two serum biochemical indices for hepatic fibrosis in schistosomiasis japonica patients one year after praziquantel treatment. Chin Med J 1997;110:797-800.

28. World Health Organization (WHO). Ultrasound in schistosomiasis. A practical guide to the standardized use of ultrasonography for the assessment of schistosomiasis-related morbidity. Second International Workshop. Niamey, Niger; 1996. 49p.

29. Wu J. Detection of hepatic fibrogenesis: a review of available techniques. Scand J Gastroenterol 1995;30:817-25.

30. Zwingenberger K, Richter J, Vergetti JG, Feldmeier H. Praziquantel in the treatment of hepatosplenic schistosomiasis: biochemical disease markers indicate deceleration of fibrogenesis and diminution of portal flow obstruction. Trans R Soc Trop Med Hyg $1990 ; 84: 252-6$ 